\title{
MULHER DE PEITO: FALANDO ABERTAMENTE SOBRE O CÂNCER DE MAMA
}

\section{Bruna Barcelos Fernandes ${ }^{1}$ \\ Mytissa Verônica Silva Grillo Alves ${ }^{2}$ \\ Klindia Ramos Barcelos ${ }^{3}$ \\ Fabiana Dável Canal ${ }^{4}$}

Resumo: O câncer de mama é o segundo tipo de neoplasia maligna mais freqüente em mulheres no mundo, e essa constatação pode ser percebida devido ao elevado número de diagnósticos em casos que a doença já se apresenta avançada. Falar sobre uma vida que imprevisivelmente vivenciou a experiência do adoecer é tocar o impalpável, é sentir dores, lutas, e perceber que ao pesquisar seu mundo, as experiências já não são mais singulares, mas compartilháveis, mesmo que em proporções distintas. Vivenciar o câncer e tudo que a doença carrega consigo é doloroso, mas é possível em meio a todo sofrimento, criar estratégias de enfrentamento diante de tudo que a doença apresenta. Desta forma, através de um relato de caso, este trabalho tem por intuito abordar a experiência de S.M.A (nome fictício para não expor a entrevistada), evidenciando a descoberta da doença e análises acerca do que vivenciou ao longo do tratamento.

Palavras-chave: Câncer de mama; Enfrentamento; Ressignificação.

\footnotetext{
1Especialização em Epidemiologia/ Universidade Federal do Espírito Santo, Brasil. E-mail: bruninhabarcelosf@gmail.com.

2 In memoriam

${ }^{3}$ Especialização em Epidemiologia/ Universidade Federal do Espírito Santo, Brasil. E-mail: klindia@hotmail.com. ${ }^{4}$ Orientadora: Mestrado em Psicologia Instrucional/ Universidade Federal do Espírito, Brasil. E-mail: fabidavel@yahoo.com.br.
} 